THE CONTRIBUTION OF FINANCIAL ENTITIES TO THE SUSTAINABLE DEVELOPMENT THROUGH THE REPORTING OF CORPORATE SOCIAL RESPONSIBILITY INFORMATION

\author{
María Consuelo Pucheta-Martínez \\ Universidad Jaume I \\ Department of Finance and Accounting \\ Campus del Riu Sec, s/n \\ 12071-Castellón- \\ Spain \\ e-mail:pucheta@uji.es \\ Inmaculada Bel-Oms \\ Universidad of Valencia \\ Departamento de Finanzas Empresariales \\ Campus de Tarongers \\ Edifici Departamental Oriental. \\ Av. dels Tarongers, s/n \\ 46022-València- \\ Spain \\ e-mail: i.beloms@hotmail.com \\ Mehdi Nekhili \\ Le Mans University \\ School of Law, Economics, and Business Administration \\ Avenue Olivier Messiaen \\ Le Mans, 72085 \\ France \\ e-mail:mehdi.nekhili@univ-lemans.fr
}




\title{
THE CONTRIBUTION OF FINANCIAL ENTITIES TO THE SUSTAINABLE DEVELOPMENT THROUGH THE REPORTING OF CORPORATE SOCIAL RESPONSIBILITY INFORMATION
}

\begin{abstract}
This paper aims at examining the relationship between board composition and corporate social responsibility (CSR) of a sample of listed financial entities, discussing the driving reasons of these entities to disclose CSR information. We hypothesize that there is a positive association between outside (institutional and independent directors) and female directors and CSR disclosure and a negative relationship between inside directors and CSR reporting. Our findings provide evidence that the proportions of independent directors and female directors on boards encourage CSR disclosure. Moreover, the results also show that the proportions of inside directors and institutional directors on boards do not have influence on CSR reporting. Thus, our evidence suggests that board attributes such as independent and female directors encourage financial entities to report CSR matters, showing the effectiveness of these two corporate governance mechanisms. The paper shed light on the influence of board structure of financial entities on CSR disclosure. Therefore, this study contributes to past research by providing an index to measure CSR disclosure of financial entities and the importance of the distinction between outside and inside directors.
\end{abstract}

Keywords: Sustainable development, corporate social responsibility reporting, insiders, outsiders, female directors, financial entities 


\section{Introduction}

The financial crisis has severely hit the world-wide, particularly commercial and investment banks, saving banks, real estate agency, venture capital firms, as well as nonfinancial companies. This negative situation has damaged the financial sector's image and the individuals' perceptions towards financial institutions since society considers them the responsible of the current worldwide economic crisis (Bravo-Urquiza et al., 2010). Unquestionably, the main economic agents such as public administrations, legislators and managers have addressed a variety of approaches to solving this problem such as improving financial assets quality or introducing corporate social responsibility (CSR) activities, among others things. In this regard, financial institutions have begun to take an interest in socially responsible actions as one of the most important decisions of the entities. The contributions of financial sector in the sustainable development are essential in the developmental activities of the world since their actions should reflect their concerns for human rights, economic and environment matters.

The term CSR has evolved over time, and currently may be defined as the firm's aims focused on social, economic and environmental concerns in business operations in order to improve the interaction with stakeholders. In this sense, board composition is one of the most important mechanisms for promoting CSR reporting (Muttakin et al. 2016), getting a growing interest by scholars. Among board characteristics impacting on CSR reporting, researchers have explored the association between the presence of insiders (Mohd-Ghazali, 2007), independent directors (Cabeza-García et al., 2017), institutional directors (Jones et al. 2008; Samara and Berbegal-Mirabent 2017) and female directors (Frías-Aceituno et al. 2013) and CRS policies. However, there are few papers based on examining how board composition of financial entities affects CSR disclosure (Das et al., 2015; Martínez-Ferrero et al., 2015; Jizi et al., 2014; 2017). Financial sector is characterized by high levels of leverage, large creditors and a great number of depositors, although they have strong regulations due to their importance for economies (Laeven et al., 2013).

This paper is relevant in CSR research because boards manage the content of annual reports, which implies that board composition may affect disclosure (Haniffa and Cooke, 2002). Accordingly, board structure of financial entities could reduce agency problems, increasing their transparency by disclosing CSR matters like in non-financial companies.

Thus, the research question of this paper is: how does board composition of financial entities impact on CSR disclosure?. In particular, this study explores the effect of insiders, 
outsiders (institutional and independent directors) and female directors on CSR disclosure. Therefore, we hypothesize that the proportion of institutional directors, independent directors and female directors on boards enhances CSR disclosure, while the proportion of insiders reduces it. In this sense, there are few papers conducted in the Spanish context in order to examine the relationship between some attributes of financial sector's boards and CSR reporting (Martínez-Ferrero et al., 2015).

Our findings show that boards of financial entities with independent and female directors are positively associated with the reporting of CSR issues. This evidence confirms the importance of outside directors such as independent directors and female directors on CSR disclosure of Spanish financial entities, in spite of the financial crisis that has led to lack of transparency, credibility and confidence in financial and non-financial disclosure. Additionally, our results also confirm that insiders and institutional directors do not have effect on CSR reporting in financial entities.

Our article notably contributes to past research in several aspects. Firstly, this study has extended a line of research based on CSR disclosure in the financial sector in both national and international context and, thus, has expanded empirical research that has focused mainly on examining the effect of CSR issues on non-financial sector. Secondly, we add to previous literature another measure of CSR disclosure focused on five dimensions: environmental, labor practices, human rights, society, and product responsibility, represented with 75 total items. This measure allows us to capture the grade of disclosure of CSR for each financial entity. Thirdly, this manuscript has widened CSR literature to the financial industry in Spanish context, which has not been generally considered by past research due to the limited number of observations, given that Spanish financial system was restructured in 2009 . Fourthly, our evidence finds the relevant role played by board structure of financial entities on CSR disclosure. In particular, it underlines the importance of categorizing outside directors into institutional and independent directors due to their different attitude toward CSR disclosure. Furthermore, independent and female directors on boards are who improve the reporting of CSR issues. In this sense, this paper supports agency theory, which postulates that independent and female directors improve the monitoring of managers. This leads to reduce agency conflicts and, ultimately, they make relevant corporate decisions such as CSR disclosure.

After this introduction, in the next section we describe the Spanish context where this paper is conducted. In the third section, we provide the theoretical background and 
hypotheses development. The fourth section provides the empirical design and the fifth section reports the results. The final section offers the conclusions, limitations and future lines of research.

\section{Spanish Context}

This study is relevant in Spain since it has been considered one of the most affected countries for the financial crisis. For this reason, the governments and financial legislators have taken serious and strong measures in order to reduce the consequences in financial entities and in society in general. The Spanish government has supported financial companies to resolve their problems, promoting the closure of most institutions, and merging the saving banks with big group of banks and nationalizing some banks, among other solutions. Spanish authorities requested support from the Eurogroup to restructure the financial sector and it committed themselves to fully implement all significant fiscal and labor market reforms and measures to strengthen the capital base of the Spanish banks (Eurogroup statement on Spain, 2012).

The restructuring of the financial sector has led to financial firms to assume new business strategies in order to survive such as growing in changing environments and restoring confidence in the economic agents such as customers or investors, among others. Over the last decade, Spain has undergone significant bank restructuring in three waves of banking. The most relevant banking merger took place during the period from 2008 to 2010, the second waves of restructuring occurred in 2012 and the last one in 2014, where Spanish banking sector went from 62 commercial banks and savings banks in 2008 to only 11 in 2017. To return the credibility and transparency in financial and non-financial information disclosure, Spanish government has developed a set of CSR initiatives such as White Book on CSR (2006) and Act 2/2011 of 4 March, Law for Sustainable Economy (2011). These proposals are aimed at enhancing the voluntary disclosure of CSR information. In this regard, Spanish CSR observatory (2014) argues that among all companies included in IBEX-35, there are only 6 firms which do not disclose relevant CSR information in their reports.

Spain has implemented several Good Corporate Governance Codes like Olivencia Code (1998), Aldama Report (2003), the Conthe Code or Unified Code of Corporate Governance (UCCG, 2006) and the updated Good Governance Code of Listed Companies (GGC, 2015) to guarantee the transparency of the markets and to protect the wealth of minority shareholders. GGC (2015) recommended that firms should develop CSR policies 
whose standards should voluntarily adhere to its dealings with stakeholder groups. According to board composition, UCCG (2006) and GGC (2015) classified board composition in insiders and outsiders. Inside directors (executive directors) are involved in the firm's management, and outsiders (external directors) are more professional and can paly a relevant role monitoring management, being classified into independent and institutional directors with different incentives in order to control managers. Heidrick and Struggles Report (2011) analyzed the composition of Spanish boards, reporting that the proportion of executive, institutional and independent directors were 15\%, 40\% and 33\%, respectively.

The UCCG (2006) also recommended the incorporation of female directors on corporate boards. Additionally, the Act 3/2007 of 22 March 2007, which called for effective equality between women and men (LOIMH), directly addressed gender diversity matters on boards, although the increase in gender quotas was gradual to $40 \%$ by 2015 . In this sense, Heidrick and Struggles Report (2014) examined the women's presence on Spanish boards and evidenced that in 2013 it was only 13\%, so the gender quotas provided by Spanish boards were not as expected. For this reason, GGC (2015) recommended that the proportion of women directors on boards should be at least $30 \%$ by 2020 .

\section{Theoretical framework and Hypotheses Development}

The complexity of financial market tends to generate opacity and severe informative asymmetries (Leventis et al., 2013; Beatty and Liao, 2015) and, therefore, financial institutions may increase governance problems and can limit the corporate control. Accordingly, corporate boards act as mechanism of corporate governance and are necessary to reduce informative asymmetries (De Andrés and Vallelado, 2008) in line with agency theory, since moneylenders and stakeholders do not have the skills to impose an effective governance in the banks (Levine, 2005). Most board attributes consist of outside and inside members, who have different behaviors and roles as board directors. Outside directors (independent and institutional directors) are seen as the supervising mechanism, since they guarantee the correct behavior of the firms in the interest of owners and stakeholders and satisfy the social responsibilities, which allow them to improve their social prestige and reputation (Zahra and Stanton, 1988). On the other hand, inside directors (executive directors) are experts on the firm and provide broader vision of strategies and direction (Hillman et al., 2000). Consequently, insiders give priority to activities that bring in short-term returns than others like CSR disclosure, which requires longer-term (Galbreath, 2017). Agency approach also 
proposes female directors as a key mechanism to control managers (Carter et al. 2003), since they may mitigate agency problems (Hillman and Daziel, 2003) encouraging CSR disclosure, which will lead to reduce informative asymmetries.

The disclosure of CSR information is considered one of the most important decisions for financial and non-financial companies. CSR has been especially visible in financial entities, since they invest great amounts of money in different causes. Financial industries have adopted CSR strategies in order to improve their reputation (Esen, 2013) and to convey their social identity to society (Bravo et al., 2012), using diverse mechanisms such as reports (Castelo-Branco and Lima Rodrigues, 2006) or websites (Vilar and Simão, 2015), among others. In this line, financial industry has become one of the main proactive investors in CSR issues (Marin et al., 2009; Truscott et al., 2009), since they are more sensitive to social problems (Carnevale et al., 2012) and their operations are more transparent since they use CSR principles (Prior and Argandona, 2008; King and Levine, 1993).

\section{Inside Directors}

Inside directors are one of the board's attribute affecting CSR disclosure. In particular, inside directors have contractual ties with firms, which allow them to make management decisions. It should be emphasized that one of the main role of them is to provide firm specific information to outside directors (Fama and Jensen, 1983). Agency oriented theorists highlight that the close ties between insiders and agents or their own insider interests may lead to opportunist behavior, instead of prevailing their responsibility toward shareholders. Adams and Ferreira (2007) provide evidence that inside directors may be unwilling to share their information with outside directors since the last directors may interfere in the CEO's strategic decisions.

In financial industries, some authors such as Bushman et al. (2004) and De Andres and Vallelado (2008) recommend an ideal combination of outside and inside directors since this combination may create more value in the banks. In particular, De Andres and Vallelado (2008) argue that executive directors on corporate boards are important to perform efficiently. In this sense, Simpson and Gleason (1999) document that inside directors did not have related with the probability of financial distress since they possessed private information of their companies. Rose (2017) provides evidence that inside directors reduce the lower credit risk exposure since it constitutes a strong balance system. In CSR issues, Galbreath (2017) states 
that inside directors prefer to invest in short term operations, which have a negative impact on CSR reporting.

According to above arguments, we support the idea that inside directors are experts on their companies and some time they tend to act in their own interests (Fama and Jensen, 1983). Self-interest could disclose less amount of CSR information since they may not consider investing in social, economic and environmental activities and, thus, CSR disclosure is greatly reduced. For this reason, it is expected that the presence of inside directors on boards will have a negative effect on CSR disclosure in financial companies, because they are focused on obtaining private benefits in short time instead of investing on CSR activities.

Thus, the following hypothesis is proposed:

Hypothesis 1: The proportion of inside directors on boards of financial entities will report lower levels of CSR information.

\section{Outside Directors}

Outside directors (institutional and independent directors) act as good monitors for shareholders' interests (Armstrong et al., 2010) supervising management team in comparison to inside directors (executive directors).

Institutional directors are defined by UGGC $(2006 ; 2015)$ as "directors who own an equity stake above or equal to the legally determined threshold for significant holdings". In this regard, institutional directors represent dominant investors in corporate boards, such as institutional investors. Institutional directors are not part of management team (inside directors) and, thus, they may influence on management's decisions (Gillan and Starks, 2003; Almazán et al., 2005).

In financial sector, institutional directors tend to represent banks and financial entities, thus, in this case they play three roles: investor, director and company's creditors. As a result, institutional investors are subject to considerable regulations in financial companies, which make them very active investors (Whidbee, 1992) and, therefore, their control is weaker in financial entities than in non-.financial companies (Elyasiani and Jia, 2008). In this sense, they have more information and knowledge of the sector and, so, they can improve the performance (Alexandre and Paquerot, 2000). Moreover, institutional directors have experience, formation and knowledge to act effectively in the control of management decisions. For this reason, these directors are considered as an effective monitor for the financial sector. Agency theory also postulates that institutional directors and, concretely, 
financial directors, have access to more information and greater experience in the performance (Jensen, 1993) and, as a consequence, they provide more efficiency and expertise to boards (Agrawal and Mandelker, 1992). Boulila-Taktak and Mbarki (2014) show that institutional directors on boards mitigate discretionary, given their reputation and experience in the industry (Louizi, 2007), which enhances firm performance.

With regard to CSR issues, Semenescu and Curmei (2015) report that investors prefer financial entities which implement CSR practices since they considered CSR activities a relevant tool for alleviating informative asymmetries. In this line, Bose et al. (2017) demonstrate that institutional ownership is positively associated with the disclosure of green information by banking industry, since financial entities intend to provide more CSR information in order to reduce agency costs such as informative asymmetries between themselves and investors.

The academic literature on CSR issues has also paid little attention to analyze the association between institutional directors and CSR disclosure. Thus, this gap in the corporate governance literature has to be filled. In this regard, we expect that financial entities' boards with institutional directors will drive managers toward effective CSR reporting in order to guarantee firm sustainability and reduce agency costs (Bolton et al., 2003).

Independent directors are defined as directors who should not have any relation with the firms that could influence their opinions or roles (UGGC, 2006; 2015). According to agency theory perspective, independent directors are an essential corporate governance mechanism for monitoring and controlling firm's managers and board effectiveness (Wang et al. 2015). Independent directors tend to have more interest in accomplishing regulations and behaviors socially responsible in firms (Jo and Hartojo, 2011) in order to safeguard their prestige and professional reputation (Pathan, 2009). In this sense, independent directors take a long view beyond firms' financial decisions and pay special attention to the social responsibility disclosure (Ibrahim et al., 2003; Jizi et al., 2014).

In financial sector, past research provides evidence that independent directors have a positive impact on CSR disclosure in different countries such as Ukraine (Mozghovyi and Ratnykova, 2011), US (Jizi et al., 2014), Bangladesh (Das et al., 2015), or Spain (MartínezFerrero et al., 2015), among others. In this line, Martínez-Ferrero et al. (2015) point out that independent directors in financial sector have the same effect than in non-financial companies, contributing to increase CSR reporting. Furthermore, Jizi et al. (2014) evidence that independent directors encourage CSR disclosure consistent with Kiliç et al. (2015), who 
demonstrate that these directors may influence on other directors to undertake CSR initiatives. Htay et al. (2012) show that independent director on corporate boards encourage social and environmental disclosure.

The inclusion of outside directors on corporate boards encourages good corporate governance and sustainability practices in companies (Johnson and Greening, 1999). When outside directors are considered as a whole in financial companies, there is a positive association between outside directors and CSR disclosure in Bangladesh and Pakistan banks (Khan, 2010; Sharif and Rashid, 2014). In particular, Khan (2010) shows that outside directors improve banks' communication on CSR information and Sharif and Rashid (2014) report that their inclusion on corporate boards may lead to a balance among companies' activities, their legitimacy and social values.

Thus, we propose that the presence of institutional and independent directors on boards will have a positive effect on CSR reporting, in line with agency theory, in order to mitigate agency conflicts between managers and owners, safeguarding shareholder's interests.

Thus, we formulate our following hypotheses:

Hypothesis 2: The proportion of institutional directors on boards of financial entities will report higher levels of CSR.

Hypothesis 3: The proportion of independent directors on boards of financial entities will report higher levels of CSR.

\section{Female directors}

In order to explore the effect of board gender diversity of financial entities on CSR disclosure, it is important to examine how female directors on boards of non-financial firms affect the decision-making process. Past empirical evidence claims the female directors play a relevant role in financial reporting quality (Pucheta-Martínez et al. 2016), dividend policy (Van Pelt 2013) or executive compensation (Lucas-Pérez et al. 2015), among others.

Agency perspective based on analyzing the relationship between board composition and CSR disclosure suggests that board gender diversity provides more board independence (Carter et al. 2007) and, consequently, it may lead to an enhanced monitoring of managers (Carter et al. 2003). This fact alleviates agency costs (Hillman and Daziel 2003) through the reporting of CSR matters. According to gender socialization theory (sociological, psychological and cognitive perspectives), female directors are characterized by their sensitiveness, friendliness and careful, which leads them to behave in a cooperative way 
(Kim, 2013), in contrast with men leaders, who are very competitive (Eagly and Carli, 2007). Similarly, Nielsen and Huse (2010) and Matsa and Miller (2013) demonstrate that women leaders are more sensitivity and attentiveness to stakeholders' demand in social responsible issues and Bear et al. (2010) find that women bring to the board sensitivity toward CSR reporting and a participatory decision-making style. It is found that women are more concerned with ethical and responsible behavior (Levi et al., 2014; Man and Wong, 2013) and, thus, they will be able to align both managers and shareholders interest and to make relevant decisions based on environmental involvements and social welfare activities (Johnson and Greening, 1999; Post et al., 2011). These behaviors drive to increase the information transparency on issues relating to CSR disclosure (Prado-Lorenzo and GarcíaSánchez, 2010; Frías-Aceituno et al., 2013). Authors such as Post et al. (2011), RodríguezAriza et al. (2014), Fernandez-Feijoo et al. (2014b), Sundarasen et al. (2016) and Jizi (2017) show that female directors on boards have a positive impact on CSR disclosure, since they are considered more benevolent and less power oriented than male counterparts (Adams \& Funk 2012). Jizi (2017) supports prior findings and reports that the inclusion of female directors on boards allows firms to allocate CSR resources rather than only financial resources.

In the context of financial entities, Kiliç et al. (2015) conduct a study based on Turkish banking industry and show that female directors on boards are positively associated with CSR outcomes, because women directors could provide different perspectives in terms of social, economic and environmental issues. In this line, Martínez-Ferrero et al. (2015) provide similar findings, and argue that female directors tend to encourage the human rights issues.

In summary, the relationship between female directors and CSR disclosure is positive, regardless of the industry type. Therefore, it is expected that women directors will encourage the disclosure of CSR matters, since they are likely to influence the effectiveness of firm's social and environmental issues (Bear et al., 2010; Liao et al., 2015). Hence, we posit the following hypothesis:

Hypothesis 4: The proportion of female directors on boards of financial entities will report higher levels of CSR.

\section{Data and methodology}

\subsection{Sample}

The sample of this study is composed of Spanish financial listed firms and the time period considered is from 2004 to 2015 . However, the number of observations is limited since 
from 2009 the Spanish Financial System was restructured and the savings banks were merged with important banks. According to Spanish Confederation of Savings Banks (CECA, Confederación Española de Cajas de Ahorros), during the five-year period, 2009-2013, in Spain disappeared 56,625 jobs and 10,378 offices between banks and savings banks. In particular, in 2009 there were 43 financial entities between banks and savings banks and in 2013, it was reduced to 10 banks. In this scenario, the big three, Santander, BBVA and CaixaBank, have managed to increase their business and to reduce the number of competitors. In this sense, our sample consisted of an unbalanced panel database of 159 firm-year observations.

CSR data was obtained from the Global Reporting Initiative (GRI) (Landrum and Ohsowski, 2018) web page and financial entities home WebPages. Corporate governance data was obtained from the Public Register of the Spanish Securities Market Commission (CNMV), where the annual corporate governance report of listed companies is disclose, while financial data was collected from the SABI (Sociedad de Análisis de Balances Ibéricos) database and from their annual financial statements.

\subsection{Variables}

The dependent variable is CSR disclosure (CSR_IND). To calculate it, we built the ratio between the aggregation of the items of five blocks (Environmental, Labor practices, Human Rights, Society and Product Responsibility) that financial entities provide and the 75 total items considered. Of the 75 items, 30 are environmental, 15 are labor practices, 11 are human rights, 10 are society and 9 product responsibility. Each item will take the value 1 if it is disclosed by the financial entity and 0, otherwise. The CSR_IND will range from 0 to 1 .

As independent variables, we consider the proportion of inside directors on boards, defined as EXEC_DIR, the proportion of institutional and independent directors on boards, labeled as INST_DIR and INDP_DIR, respectively, and, finally, the proportion of female directors on boards, defined as WOM_DIR.

Several control variables have been used supported by prior research. The first control variable considered is CEO duality, measured as a dummy variable that takes the value 1 if the same person serves simultaneously as CEO and President of the board and 0, otherwise. Furthermore, we also control ownership concentration, defined as OWNCON. Board Size (BDSIZE) is calculated as the total number of directors on boards. The leverage of financial entities is also controlled. This variable is labeled as LEV and it is calculated as the ratio of 
debt over total assets (Dalla Via and Perego, 2018). The return on assets (ROA) is also considered as a control variable, measured as the operate income before interests and taxes over total assets. Finally, the proxy for firm size (FIRMSIZE) is approximated by the log of total sales. We have built the Figure 1, which summarizes the main ideas of this research.

Insert Figure 1 here

Based on above definitions of dependent, independent and control variables, we suggest the following equation in order to estimate the hypotheses proposed:

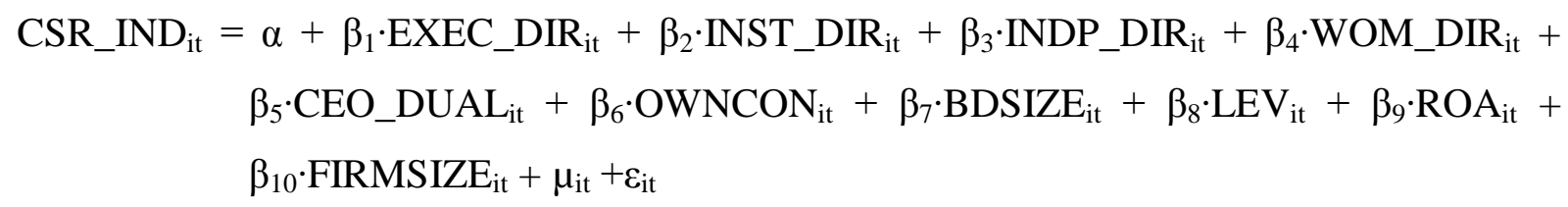

where year fixed and firm fixed effects are represented by $\mu$ it and the error by eit. Firm fixed effects take into account regular and non-observable features of financial entities that are potentially relative to CSR reporting.

We have considered that the best methodology to estimate our model is the Tobit regression model for panel data, since it allows us to use a dependent variable with limits on the left- or right-censoring. The dependent variable, CSR_IND, ranges between 0-1, inclusive, and, as a consequence, it is censored on two sides (0-1). Table 1 reports a summary of the description variables.

Insert Table 1 here

\section{Results}

\subsection{Descriptive Statistics}

Table 2 summarizes the descriptive statistics (mean, standard deviation and percentiles) for the dependent, independent and control variables. As shown, 0.601 out of 1 of the Spanish listed financial entities in our sample disclose CSR information, which can be considered as a medium-high level, if we take into account that in Spain the disclosure of CSR issues is voluntary. In addition, the results reveal that the proportions of insiders, institutional and independent directors are, on average, $25.95 \%, 33.42 \%$ and $34.30 \%$, respectively. According to board gender diversity, the percentage of female directors on boards is $14.98 \%$. With regard to control variables, the proportion of ownership concentration 
is $34.43 \%$ and the return on assets is $-0.34 \%$. Concerning the leverage of financial entities, on average, is $81.62 \%$, the firm size is 17.22 and board size is, on average, 14.63 members.

\section{Insert Table 2 here}

Table 3 provides the correlation coefficients of all the variables. According to the figures displayed in the Table 3, any of the coefficients is higher than 0.80 (Carcello and Neal, 2000). Hence, this evidence allows us to corroborate that multicollinearity is not a problem.

Insert Table 3 here

\subsection{Baseline Regressions}

Table 4 shows the results for the models estimated. We have built four models. Model 1 analyses the association between insiders and CSR disclosure, Model 2 the relationship between institutional directors and CSR reporting, Model 3 the association between independent directors and CSR disclosure and, finally, Model 4 explores the relationship between female directors and CSR reporting.

Insert Table 4 here

In Model 1, we examine the effect of inside directors (EXEC_DIR) on CSR disclosure in financial entities. The findings show that the variable executive directors present the expected sign, but it is not statistically significant. Hence, the first hypothesis cannot be accepted. This result supports the view that financial entities with inside directors on boards discourage CSR disclosure. Similar results were reported by Eng and Mak (2003), MohdGhazali (2007) and Galbreath (2015; 2017). This finding implies that inside directors prefer to obtain private benefits in a short time instead of encouraging CSR reporting. This evidence suggests that inside directors are not willing to share private information with shareholders and stakeholders, particularly when the disclosure is voluntary as it is the case of CSR information. Thus, insiders will not engage with CSR matters and, therefore, they will not support the reporting of CSR issues.

The results in Model 2 show that the variable institutional directors (INST_DIR) also exhibit the expected sign, but it is not statistically significant. Therefore, the second hypothesis has to be rejected. Our results suggest that in financial entities, institutional directors on boards do not have influence on CSR reporting. These findings are in line with Boussaada and Karmanit (2015), Htay et al. (2012) and Ghabayen et al. (2016), who 
demonstrate that institutional directors are not associated with the disclosure of CSR issues. Our evidence suggests that institutional directors are more focused on accomplishing the interest of banks, investment institutions, insurance companies or funds, among others, where the main goal is maximizing benefits rather than improving social and environmental disclosure. A possible justification of this effect could be explained because institutional investors represented in financial entities' boards do not pressure these entities to consider CSR practices in their business culture (see Oh et al., 2013). Many institutional investors are banks and have business relations with the financial entities where they sit on their boards. Thus, these institutional investors will be interested in not losing their commercial ties and will align their interests with those of insiders and will not support the reporting of CSR information.

In Model 3, the variable denoting independent directors on boards, INDP_DIR, presents the expected sign and it is statistically significant, as predicted. Thus, according to this finding, the third hypothesis cannot be rejected and suggests that the presence of independent directors on boards enhances CSR disclosure, in line with authors such as Jizi et al. (2014), Das et al. (2015), Martínez-Ferrero et al. (2015). This evidence suggests that the proportion of independent directors on boards has a positive effect on the disclosure of CSR information, since they tend to pressure companies to consider CSR issues as an important factor in the decision making process. Our findings support the thesis that this typology of directors contributes to the effective management of financial entities by increasing CSR disclosure. These directors are appointed by their professional background and their experience and expertise in the industry, among others. Additionally, independent directors will feel freer to make decisions, will not be under the pressure from managers and will defend shareholders' interests, specifically minority shareholders, and all stakeholders' demands. Therefore, board independence will encourage the disclosure of CSR matters.

Model 4 shows that the variable female directors on boards (WOM_DIR) provides the predicted sign and it is statistically significant. Hence, the fourth hypothesis cannot be rejected. The findings suggest that the presence of female directors on boards increases the reporting of CSR matters. This evidence is also corroborated by Kiliç et al. (2015) and Martínez-Ferrero et al. (2015), who demonstrate that female directors on boards in financial entities enhance CSR disclosure, because they are more dedicated to social, economic and environmental activities than men. This finding is consistent with that obtained by Levi et al. (2014) and Man and Wong (2013), who support the view that female directors have an ethical 
and responsible behavior and have a more cooperative perspective. Furthermore, women directors are more sensible with environmental and social issues and, as a result, they will be more likely to report CSR information.

According to the control variables, the variable CEO duality (CEO_DUAL) and firm size (FIRMSIZE) present the expected sign and are statistically significant in all Models estimated. In accordance with agency theory, this result suggests that CEO duality has a negative effect on CSR since it may reduce the effectiveness of the monitoring role of directors and may limit the transparency both to inside and outside stakeholders (Sundarasen et al., 2016). In contrast, the variable firm size has a significant influence on the protection of shareholder's interest and resolution of agency problems since it is positively associated with CSR disclosure. The rest of control variables are insignificant.

To reduce concerns related to endogeneity, we wonder whether inside, outside and female directors have a positive or negative association between CSR disclosure or, whether companies which disclose more or less CSR information induce these directors to join boards. Causality appears in the association between inside, outside and female directors and CSR disclosure, although reverse causality might be also a concern in our model. Endogeinity has been addressed, consistent with Hartzell and Sarks (2003), lagging our independent variables. The findings, unreported for the sake of brevity, are consistent with our core findings.

\section{Conclusions}

This study explores the role of insiders, outsiders (institutional and independent) and female directors on boards of financial entities on CSR reporting. This manuscript contributes to fill a gap in prior literature since it links board composition and CSR disclosure among Spanish financial listed entities during the period 2004-2015.

The results of this paper shed light on the influence of board structure on CSR disclosure in financial entities. First, our results find that there is not association between inside directors on boards and CSR disclosure. Our results suggest that inside directors are employees of the firms and thus, their main goal for them may be maximizing the benefits in a short horizon and the implementation and benefits of CSR activities tend to be a long-term (Galbreath, 2017). Our study provides evidence that institutional directors do not have influence on CSR disclosure of financial entities as evidenced by Htay et al. (2012) and Ghabayen et al. (2016). Moreover, this manuscript demonstrates that independent directors on boards increase CSR disclosure in the banking industry. This finding suggests that the 
presence of independent directors on boards generates a balance in firms' activities, in particular between legitimacy and social values, and improves the reporting of CSR information, enhancing the communication of financial entities (Khan, 2010). Our results also demonstrate that financial firms with female directors on boards are positively associated with CSR disclosure, in line with Kiliç et al. (2015) and Martínez-Ferrero et al. (2015). This finding supports the premise that female leadership style is cooperative, benevolent and less power oriented and women directors are very concern about social and environmental issues and, thereby, they will tend to promote the disclosure of CSR information.

This research provides both theoretical and practical implications. First, the findings report that independent and female directors become relevant drivers of CSR disclosure in financial entities. Contrary to this evidence, insiders and institutional directors on boards of financial entities do not have effect on the reporting of CSR matters in financial entities. Thus, policy-makers should recommend a higher presence of independent and women directors on boards of financial entities, and the minimum proportion of insiders and institutional directors. Financial entities should also take into account their board composition, given the impact of their directors on CSR disclosure, whether they are interested in getting legitimacy by society and all stakeholders and whether they are willing to convey their commitment with social and environmental issues. Second, board independence and board gender diversity of Spanish financial entities are significant corporate governance mechanism since they improve the transparency of non-financial information of these entities. In this way, financial entities may restore the confidence and credibility to investors and society in general. Hence, Spanish policy-setters should consider the possibility of forcing financial entities to report CSR information. Third, the Spanish corporate governance codes, Conthe code, (UGGC, 2006, 2015) and the Act 3/2007 highlighted the relevance of incorporating women directors on boards, recommending a voluntary gradual increase of gender quotas, although these recommendations were not completely effective because the gender quotas were not reached. For this reason, regulatory bodies should give a more step and reconsider the recommendations of the presence of female directors on boards of financial entities, given their positive effect on the reporting of CSR matters. The presence of female directors on financial entities' boards should be supported by a norm, requiring a minimum of their presence. Finally, this research should encourage other investigators to find out more on the relationship between other board attributes of financial entities and CSR disclosure. Other characteristics such as directors' background, the role duality (CEO and chairman of the 
board) by a woman, the ownership structure or the temporal orientation of their directors, among others, merit more attention.

A few caveats are worth noting. First, this manuscript is focused on Spanish financial listed firms for the period from 2004 to 2015. Hence, the results obtained should not be extrapolated to other periods and non-listed firms. Second, our database was built with financial companies, but Spanish financial system was restructured in 2009 as a result of the worldwide financial crisis. Consequently, the number of financial entities remaining in the Spanish financial system is limited.

Our results suggest opportunities for further research. Firstly, we encourage other researchers to do more research on the association between board composition of financial entities and CSR reporting, extending it to other board attributes rather than typology of directors such as professional background, experience, knowledge, skills and expertise, among others. Secondly, it would be interesting to examine the impact of different types of female directors such as inside, independent and institutional women directors on CSR reporting in financial sector.

\section{References}

Act 2/2011, of 4 March, Law for Sustainable Economy

Act 3/2007, of 22 March, for Effective Equality between Women and Men.

Adams, R.B. and Funk, P. (2012). Beyond the glass ceiling: does gender matter? Management science, 58(2): 219-235

Adams, R.B. and Ferreira, D. (2007). A theory of friendly boards. Journal of Finance, 62(1): 217-250.

Agrawal, A. and Mandelker, G.N. (1992). Shark repellents and the role of institutional investors in corporate governance. Managerial and Decision Economics, 13(1): 1522.

Aldama Report (2003). Informe de la Comisión Especial para el Fomento de la transparencia y la Seguridad en los Mercados Financieros y en las Sociedades Cotizadas. Madrid: Ministerio de Economía y Hacienda.

Alexandre, H. and Paquerot, M. (2000). Efficacité des structures de contrôle et enracinement des dirigeants. Finance Contrôle Stratégie, 3(2): 5-29.

Almazan, A., Hartzell, J.C. and Starks, L. T. (2005). Active institutional shareholders and costs of monitoring: Evidence from executive compensation. Financial Management, 34(4): 5-34.

Armstrong, C. S., Guay, W.R. and Weber, J.P. (2010). The role of information and financial reporting in corporate governance and debt contracting. Journal of Accounting and Economics, 50(2-3): 179-234.

Bear, S., Rahman, N. and Post, C. (2010). The impact of board diversity and gender composition on corporate social responsibility and firm reputation. Journal of Business Ethics, 97(2): 207-221. 
Beatty, A. and Liao, S. (2015). Does Loan Loss Provision Timeliness Affect the Accuracy, Informativeness, and Predictability of Analyst Provision Forecasts?. The Ohio State University and University of Toronto Working Paper.

Boulila-Taktak, N. and Mbarki, I. (2014). Board characteristics, external auditing quality and earnings management: evidence from the Tunisian banks. Journal of Accounting in Emerging Economies, 4(1): 79-96.

Boussaada, R. and Karmani, M. (2015). Did Board of Directors Have an Impact on MENA Bank Performance?. International Journal of Economics and Finance, 7(4), 46-56.

Bose, S., Khan, H. Z., Rashid, A., \& Islam, S. (2017). What drives green banking disclosure? An institutional and corporate governance perspective. Asia Pacific Journal of Management, 1-27.

Bolton LE, Warlop L, Alba JW. 2003. Consumer perceptions of price (un)fairness. Journal of Consumer Research, 29: 474-91.

Bravo-Urquiza, F. B., Navarro, M. C. A. and Trombetta, M. (2010). Disclosure theories and disclosure measures. Spanish Journal of Finance and Accounting/Revista Española de Financiación y Contabilidad, 39(147): 393-420.

Bushman, R., Chen, Q., Engel, E. and Smith, A. (2004). Financial accounting information, organizational complexity, and corporate governance systems. Journal of Accounting and Economics, 37(2): 167-201.

Cabeza-García, L., Sacristán-Navarro, M. and Gómez-Ansón, S. (2017). Family involvement and corporate social responsibility disclosure. Journal of Family Business Strategy, 8(2): 109-122.

Carnevale, C., Mazzuca, M. and Venturini, S. (2012). Corporate social reporting in European banks: The effects on a firm's market value. Corporate Social Responsibility and Environmental Management, 19(3): 159-177.

Carter, D. A., Simkins, B.J. and Simpson, W.G. (2003). Corporate governance, board diversity, and firm value. Financial review, 38(1): 33-53.

Carter, D., D'Souza, F.P., Simkins, B.J. and Simpson, W.G. (2007). The diversity of corporate board committees and firm financial performance. (March 15, 2007). Available at SSRN: https://ssrn.com/abstract=972763 or http://dx.doi.org/10.2139/ssrn.972763

Castelo-Branco, M. and Lima-Rodrigues, L. (2006). Communication of corporate social responsibility by Portuguese banks: A legitimacy theory perspective. Corporate Communications: An International Journal, 11(3): 232-248.

Dalla Via, N., and Perego, P. (2018) Determinants of conflict minerals disclosure under the Dodd-Frank Act. Business Strategy and the Environment, Doi: 10.1002/bse.2030.

Das, S. and Dixon, R. and Michael, A. (2015). Corporate Social Responsibility Reporting: A Longitudinal Study of Listed Banking Companies in Bangladesh (January 30, 2015). World Review of Business Research, 5(1), Jan 2015. Available at SSRN: https://ssrn.com/abstract $=2579814$

De Andres, P. and Vallelado, E. (2008). Corporate governance in banking: The role of the board of directors. Journal of banking \& finance, 32(12): 2570-2580.

Eagly, A.H. and Carli, L.L. (2007). Women and the labyrinth of leadership. Harvard business review, 85(9).

Elyasiani, E. and Jia, J.J. (2008). Institutional ownership stability and BHC performance. Journal of Banking and Finance, 32(9): 1767-1781.

Eng, L.L. and Mak, Y.T. (2003). Corporate governance and voluntary disclosure. Journal of Accounting and Public Policy, 22(4): 325-45. 
Esen, E. (2013). The influence of corporate social responsibility (CSR) activities on building corporate reputation. In International business, sustainability and corporate social responsibility (pp. 133-150). Emerald Group Publishing Limited.

Eurogroup statement on Spain, 9 June 2012

Fama, E.F. and Jensen, M.C. (1983). Separation of ownership and control. The journal of law and Economics, 26(2): 301-325.

Fernandez-Feijoo, B., Romero, S. and Ruiz-Blanco, S. (2014). Women on boards: do they affect sustainability reporting? Corporate Social Responsibility and Environmental Management, 21(6): 351-364.

Frías-Aceituno, J.V., Rodríguez-Ariza, L. ad García-Sánchez, I.M. (2013). Is integrated reporting determined by a country's legal system? An exploratory study. Journal of cleaner production, 44: 45-55.

Galbreath, J. (2015). Whither the Inside Director? A Study of Corporate Governance and CSR (WITHDRAWN). Academy of Management Proceedings. Vol. 2015. No. 1. Academy of Management, 2015.

Galbreath, J. (2017). The impact of board structure on corporate social responsibility: a temporal view. Business Strategy and the Environment, 26(3): 358-370.

Ghabayen, M.A., Mohamad, N.R. and Ahmad, N. (2016). Board characteristics and corporate social responsibility disclosure in the Jordanian banks. Corporate Board: Role, Duties \& Composition, 12(1): 84-100.

Gillan, S. and Starks, L. (2003). Corporate governance, corporate ownership, and the role of institutional investors: A global perspective. (August 2003). Weinberg Center for Corporate Governance Working Paper No. 2003-01. Available at SSRN: https://ssrn.com/abstract $=439500$

Good Governance Code of Listed Companies. GGC. (2015). Acuerdo del Consejo de la Comisión Nacional del Mercado de Valores de 18 de febrero de 2015 sobre el código de buen gobierno de las sociedades cotizadas. CNMV. Madrid, Spain.

Haniffa, R.M. and Cooke, T.E. (2002). Culture, corporate governance and disclosure in Malaysian corporations. Abacus, 38(3): 317-349.

Hartzell, J.C. and Starks, L.T. (2003). Institutional investors and executive compensation. Journal of Finance, 58(6): 2351-2374.

Heidrick and Struggles (2011). Challenging board performance. European report on corporate governance: Chicago, IL: Heidrick \& Struggles

Heidrick \& Struggles. (2014). Towards dynamics governance 2014. European corporate governance report. Chicago, IL: Heidrick \& Struggles

Hillman, A.J. and Dalziel, T. (2003). Boards of directors and firm performance: Integrating agency and resource dependence perspectives. Academy of Management review, 28(3): 383-396.

Hillman, A.J., Cannella, A.A. and Paetzold, R.L. (2000). The resource dependence role of corporate directors: Strategic adaptation of board composition in response to environmental change. Journal of Management studies, 37(2): 235-256.

Htay, S.N.N., Ab Rashid, H.M., Adnan, M.A. and Meera, A.K.M. (2012). Impact of corporate governance on social and environmental information disclosure of Malaysian listed banks: Panel data analysis. Asian Journal of Finance \& Accounting, 4(1): $1-24$.

Ibrahim, N. A., Howard, D. P. and Angelidis, J. P. (2003). Board members in the service industry: An empirical examination of the relationship between corporate social responsibility orientation and directorial type. Journal of Business Ethics, 47(4): 393401. 
Jensen, M. C. (1993). The modern industrial revolution, exit, and the failure of internal control systems. The Journal of Finance, 48(3): 831-880.

Jizi, M. (2017). The influence of board composition on sustainable development disclosure. Business Strategy and the Environment, 26(5): 640-655.

Jizi, M.I., Salama, A., Dixon, R. and Stratling, R. (2014). Corporate governance and corporate social responsibility disclosure: Evidence from the US banking sector. Journal of Business Ethics, 125(4): 601-615.

Jo, H. and Harjoto, M.A. (2011). Corporate governance and firm value: The impact of corporate social responsibility. Journal of business ethics, 103(3): 351-383.

Johnson, R.A. and Greening, D.W. (1999). The effects of corporate governance and institutional ownership types on corporate social performance. The Academy of Management Journal, 42(5): 564-576.

Jones, C.D., Makri, M. and Gomez- Mejia, L.R. (2008). Affiliate directors and perceived risk bearing in publicly traded, family-controlled firms: The case of diversification. Entrepreneurship Theory and Practice, 32(6): 1007-1026.

Khan, H.U.Z. (2010). The effect of corporate governance elements on corporate social responsibility (CSR) reporting: Empirical evidence from private commercial banks of Bangladesh. International Journal of Law and Management, 52(2): 82-109.

Kiliç, M., Kuzey, C. and Uyar, A. (2015). The impact of ownership and board structure on Corporate Social Responsibility (CSR) reporting in the Turkish banking industry. Corporate Governance, 15(3): 357-374.

Kim, H. (2013). Glass fence thicker than glass ceiling: The puzzling gaps of women's leadership in Korea. In J. Rajasekar (Ed.), Culture and gender in leadership: Perspectives from the Middle East and Asia (pp. 253-274). Hampshire, England: Palgrave Macmillan.

King, R.G. and Levine, R. (1993). Finance and growth: Schumpeter might be right. The quarterly journal of economics, 108(3): 717-737.

Laeven, L. (2013). Corporate governance: what's special about banks?. Annu. Rev. Financ. Econ., 5(1): 63-92.

Landrum, N. E., and Ohsowski, B. (2018) Identifying worldviews on corporate sustainability: A content analysis of corporate sustainability reports. Business Strategy and the Environment, 27(1): 128-151.

Leventis, S., Dimitropoulos, P. and Owusu-Ansah, S. (2013). Corporate governance and accounting conservatism: Evidence from the banking industry. Corporate Governance: An International Review, 21(3): 264-286.

Levi, M., K. Li and F. Zhang (2014). Director Gender and Mergers and Acquisitions. Journal of Corporate Finance, 28: 185-200.

Levine, R. (2005). Finance and growth: theory and evidence. Handbook of economic growth, 1(A): 865-934.

Liao, L., Luo, L. and Tang, Q. (2015). Gender diversity, board independence, environmental committee and greenhouse gas disclosure. The British Accounting Review, 47(4): 409424.

Louizi, G. (2007). Role of the Board in Banks' Governance and Impact on Performance: Case of Tunisian Banks. i-Manager's Journal on Management, 2(3), 38-55.

Lucas-Pérez, M.E., Mínguez-Vera, A., Baixauli-Soler, J.S., Martín-Ugedo, J.F. and Sánchez-Marín, G. (2015). Women on the board and managers' pay: Evidence from Spain. Journal of Business Ethics, 129(2): 265-280. 
Marin, L., Ruiz, S. and Rubio, A. (2009). The role of identity salience in the effects of corporate social responsibility on consumer behavior. Journal of Business ethics, 84(1): 65-78.

Martínez-Ferrero, J., Vaquero-Cacho, L.A., Cuadrado-Ballesteros, B. and García-Sánchez, I.M. (2015). El gobierno corporativo y la responsabilidad social corporativa en el sector bancario: el papel del consejo de administración. Investigaciones Europeas de Dirección y Economía de la Empresa, 21(3): 129-138.

Matsa D.A. and Miller A.R. (2013). A female style in corporate leadership? Evidence from quotas. American Economic Journal, 5(3): 136-169

Mohd-Ghazali, N.A. (2007). Ownership structure and corporate social responsibility disclosure: some Malaysian evidence. Corporate Governance: The International Journal of Business in Society, 7(3): 251-266.

Mozghovyi, Y. and Ratnykova, I. (2011). Correlation between the Corporate Social Responsibility and Financial Performance of the Bank in Ukrainian Context. Corporate Ownership and Control, 8(2): 120-130, 2011. Available at SSRN: https://ssrn.com/abstract=2536878

Muttakin, M.B., Khan, A. and Mihret, D.G. (2016). The effect of board capital and CEO power on corporate social responsibility disclosures. Journal of Business Ethics, 1-16.

Nielsen, S. and Huse, M. (2010). The contribution of women on boards of directors: Going beyond the surface. Corporate Governance: An International Review, 18(2): 136-148.

Oh, C.H., Park, J.H. and Ghauri, P.N. (2013). Doing right, investing right: Socially responsible investing and shareholder activism in the financial sector. Business Horizons, 56(6): 703-714.

Olivence Report (1998). El Buen Gobierno de las Sociedades. Madrid: Ministerio de Economía y Hacienda, Madrid.

Pathan, S. (2009). Strong boards, CEO power and bank risk-taking. Journal of Banking \& Finance, 33(7): 1340-1350.

Post, C., Rahman, N. and Rubow, E. (2011). Green governance: Boards of directors' composition and environmental corporate social responsibility. Business \& Society, 50(1): 189-223.

Prado-Lorenzo J.M. and García-Sánchez, I.M. (2010). The role of board of directors in disseminating relevant information on greenhouse gases. Journal of Business Ethics, 97(3): 391-424.

Prior, F. and Argandoña, A. (2008). Best practices in credit accessibility and corporate social responsibility in financial institutions. Journal of Business Ethics, 87: 251-265.

Pucheta-Martínez, M.C., Bel-Oms, I. and Olcina-Sempere, G. (2016). Corporate governance, female directors and quality of financial information. Business Ethics: A European Review, 25(4): 363-385.

Rodríguez-Ariza, L., Aceituno, J.V.F. and Rubio, R.G. (2014). El consejo de administración y las memorias de sostenibilidad. Revista de Contabilidad, 17(1): 5-16.

Rose, C. (2007). Does female board representation influence firm performance? The Danish evidence. Corporate Governance: An International Review, 15(2): 404-413.

Samara, G. and Berbegal-Mirabent, J. (2017). Independent directors and family firm performance: does one size fit all?. International Entrepreneurship and Management Journal, 1-24.

Semenescu, A. and Curmei, C. V. (2015). Using CSR to mitigate information asymmetry in the banking sector. Management \& Marketing, 10(4): 316-329. 
Sharif, M. and Rashid, K. (2014). Corporate governance and corporate social responsibility (CSR) reporting: an empirical evidence from commercial banks (CB) of Pakistan. Quality \& Quantity, 48(5): 2501-2521.

Simpson, W.G. and Gleason, A.E. (1999). Board structure, ownership, and financial distress in banking firms. International Review of Economics \& Finance, 8(3): 281-292.

Spanish CSR observatory report (2014). La responsabilidad Social Corporativa en las memorias anuales de las empresas del IBEX35. Análisis del ejercicio 2014. Director Coordinador: Orencio Vázquez

Sundarasen, S.D.D., Je-Yen, T. and Rajangam, N. (2016). Board composition and corporate social responsibility in an emerging market. Corporate Governance: The International Journal of Business in Society, 16(1):, 35-53.

Truscott, R.A., Bartlett, J.L. and Tywoniak, S. A. (2009). The reputation of the corporate social responsibility industry in Australia. Australasian Marketing Journal (AMJ), 17(2): 84-91.

Unified Code of Corporate Governance. UCCG. (2006). Informe del Grupo Especial de Trabajo sobre Buen Gobierno de las Sociedades Cotizadas, Comité Conthe. Madrid.

Van Pelt, T. (2013). The effect of board characteristics on dividend policy. Tilburg: Tilburg University.

Vilar, V.H. and Simão, J. (2015). CSR disclosure on the web: major themes in the banking sector. International Journal of Social Economics, 42(3): 296-318.

Wang, C., Xie, F. and Zhu, M. (2015). Industry expertise of independent directors and board monitoring. Journal of Financial and Quantitative Analysis, 50(5): 929-962.

Whidbee, D.A. (1997). Board composition and control of shareholder voting rights in the banking industry. Financial Management, 26 (4): 27-41.

White Book in Spain on CSR (Libro Blanco de la RSE en España) (2006). Boletín Oficial de las Cortes Generales/n' $424 / 4$ de agosto de 2006. Madrid, Spain. http://www.congreso.es

Zahra, S.A. and Stanton, W.W. (1988). The implications of Board of Directors composition on corporate strategy and performance, International Journal of Management, 5(2): 229-236. 
Figure 1

Research Framework

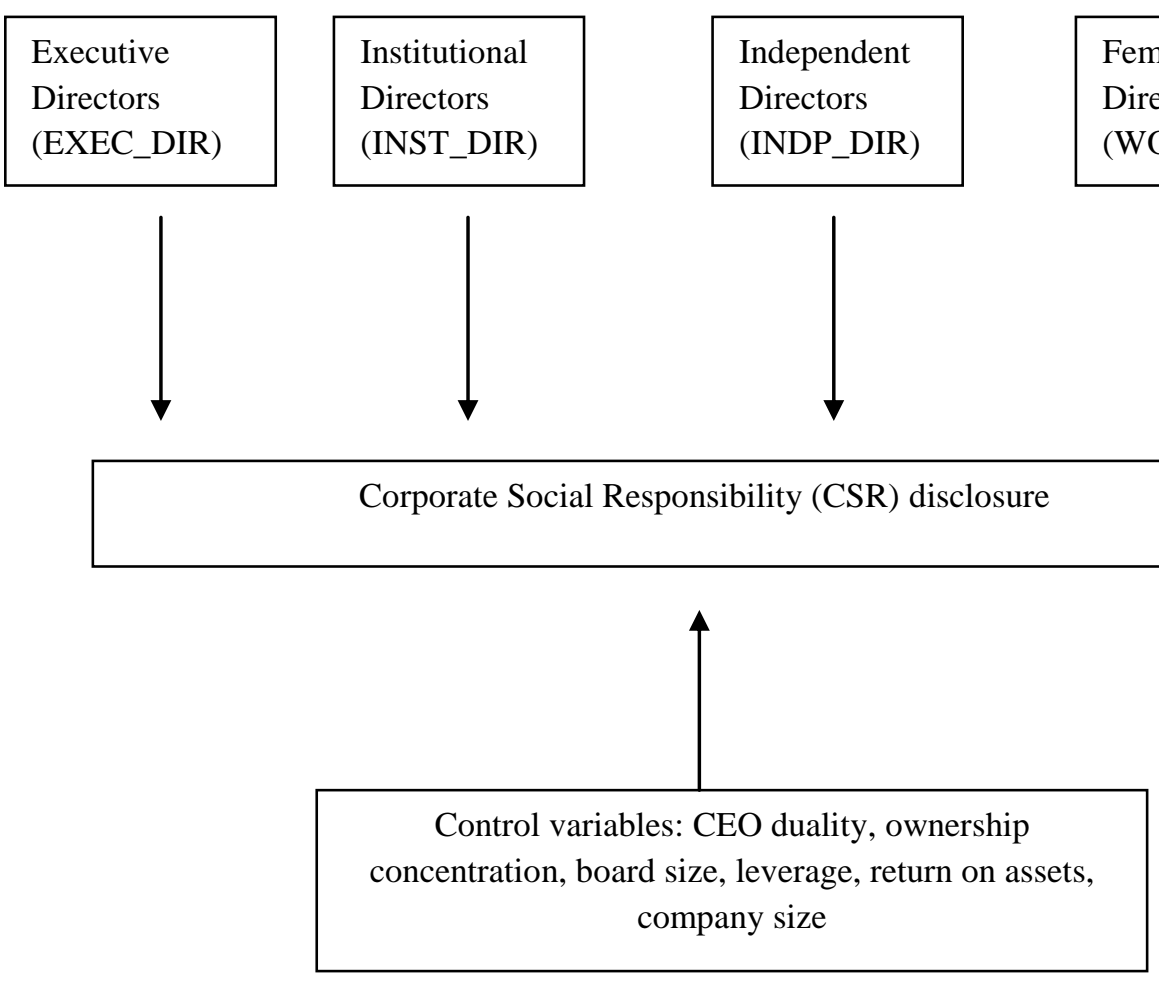

Table 1

Variable description

\begin{tabular}{|c|c|}
\hline Variables & Description \\
\hline CSR_IND & $\begin{array}{l}\text { The ratio between the aggregation of the items of five blocks (Environmental, Labour practices, } \\
\text { Human Rights, Society, Product Responsibility) that the financial entity provides and the } 75 \text { total } \\
\text { items considered. The item will take the value } 1 \text { if it is disclosed by the financial entity and } 0 \text {, } \\
\text { otherwise. }\end{array}$ \\
\hline EXEC_DIR & Proportion of executive directors on board \\
\hline INST_DIR & Proportion of institutional directors on board \\
\hline INDP_DIR & Proportion of independent directors on board \\
\hline WOM_DIR & Proportion of female directors on boards \\
\hline CEO_DUAL & $\begin{array}{l}\text { Dummy variable equals to } 1 \text { if the same person serves simultaneously as CEO and President of the } \\
\text { board and } 0 \text {, otherwise }\end{array}$ \\
\hline OWNCON & The ownership concentration in the firm \\
\hline BDSIZE & The number of directors on boards \\
\hline LEV & Debt over total assets \\
\hline ROA & Operate income before interests and taxes over total assets \\
\hline FIRMSIZE & The log of total sales \\
\hline
\end{tabular}


Table 2

Main descriptive statistics

Mean, standard deviation and percentiles. Panel A and B show the continuous and dummy variables, respectively. CSR_IN is measured as the ratio between the aggregation of the items that the firm provides of a total of 5 items and the total items considered; EXEC_DIR is the proportion of executive directors on board; INST_DIR is the proportion of institutional directors on board; IDEP_DIR is the proportion of independent directors on boards; WOM_DIR is the proportion of female directors on boards; CEO_DUAL is calculated as Dummy variable equals to 1 if the same person serves simultaneously as CEO and President of the board and zero, otherwise; OWNCON is the ownership concentration in the firm; BDSIZE is the number of directors on boards; LEV is the debt over total assets; ROA is the operate income before interests and taxes over total assets; FIRMSIZE is the log of total sales.

\begin{tabular}{|c|c|c|c|c|c|c|}
\hline \multicolumn{7}{|c|}{ Panel A. Continuous variables } \\
\hline Variables & $\mathbf{N}$ & Mean & Std. Dev. & Perc. 25 & Perc. 50 & Perc. 75 \\
\hline CSR_IND & 159 & 0.601 & 0.181 & 0.467 & 0.587 & 0.747 \\
\hline EXEC_DIR & 159 & $25.948 \%$ & $17.978 \%$ & $14.286 \%$ & $21.429 \%$ & $31.579 \%$ \\
\hline INST_DIR & 159 & $33.417 \%$ & $24.170 \%$ & $13.334 \%$ & $31.250 \%$ & $52.941 \%$ \\
\hline INDP_DIR & 159 & $34.297 \%$ & $21.456 \%$ & $20.000 \%$ & $33.334 \%$ & $50.000 \%$ \\
\hline WOM_DIR & 159 & $14.979 \%$ & $11.073 \%$ & $8.334 \%$ & $14.286 \%$ & $20.000 \%$ \\
\hline OWNCON & 159 & $34.430 \%$ & $37.769 \%$ & $0 \%$ & $15.226 \%$ & $67.800 \%$ \\
\hline BDSIZE & 159 & 14.629 & 5.296 & 11.000 & 14.000 & 18.000 \\
\hline LEV & 159 & $81.620 \%$ & $25.283 \%$ & $88.144 \%$ & $93.302 \%$ & $94.829 \%$ \\
\hline ROA & 159 & $-0.342 \%$ & $39.530 \%$ & $0.158 \%$ & $0.558 \%$ & $1.010 \%$ \\
\hline FIRMSIZE & 159 & 17.216 & 2.027 & 16.047 & 17.599 & 18.841 \\
\hline \multicolumn{7}{|c|}{ Panel B. Dummies variables } \\
\hline & & & $\mathbf{0}$ & $\%(0)$ & 1 & $\%(1)$ \\
\hline CEO_DUAL & & & 150 & 94.396 & 9 & $5.604 \%$ \\
\hline
\end{tabular}


Table 3

\section{Correlation Matrix}

Correlation matrix. CSR_IN is measured as the ratio between the aggregation of the items that the firm provides of a total of 5 items and the total items considered; EXEC_DIR is the proportion of executive directors on board; INST_DIR is the proportion of institutional directors on board; INDP_DIR is the proportion of independent directors on boards; WOM DIR is the proportion of female directors on boards; CEO DUAL is calculated as Dummy variable equals to 1 if the same person serves simultaneously as CEO and President of the board and zero, otherwise; OWNCON is the ownership concentration in the firm; BDSIZE is the number of directors on boards; LEV is the debt over total assets; ROA is the operate income before interests and taxes over total assets; FIRMSIZE is the log of total sales. Significant at $* * *$ for 99 percent confidence level, ** for 95 percent and $*$ for 90 percent.

\begin{tabular}{|c|c|c|c|c|c|c|c|c|c|c|}
\hline & CSR_IND & $\begin{array}{l}\text { EXEC_DIR } \\
\end{array}$ & INST_DIR & INDP_DIR & WOM_DIR & CEO_DUAL & OWNCON & BDSIZE & LEV & ROA \\
\hline EXEC_DIR & 0.090 & & & & & & & & & \\
\hline INST_DIR & -0.056 & $-0.362 * * *$ & & & & & & & & \\
\hline INDP_DIR & 0.026 & $-0.324 * * *$ & $-0.574 * * *$ & & & & & & & \\
\hline WOM_DIR & -0.077 & -0.073 & $0.267 * * *$ & $-0.235 * *$ & & & & & & \\
\hline CEO_DUAL & $-0.156^{*}$ & $0.136^{*}$ & $-0.250 * * *$ & $0.201 * *$ & -0.053 & & & & & \\
\hline OWNCON & $-0.138 *$ & $0.198 * *$ & $0.307 * * *$ & $-0.310 * * *$ & $0.251 * * *$ & -0.087 & & & & \\
\hline BDSIZE & $0.174 * *$ & $0.315 * * *$ & -0.081 & -0.064 & 0.034 & 0.071 & $0.140^{*}$ & & & \\
\hline LEV & -0.058 & $0.180 * *$ & -0.127 & -0.117 & 0.009 & -0.021 & 0.072 & -0.129 & & \\
\hline ROA & 0.024 & 0.022 & -0.078 & $0.175^{* *}$ & $-0.298 * * *$ & -0.091 & 0.067 & $0.191 * *$ & $-0.355 * * *$ & \\
\hline FIRMSIZE & 0.088 & $0.173 * *$ & $-0.530 * * *$ & $0.376^{* * *}$ & -0.018 & $0.335 * * *$ & $-0.331 * * *$ & $0.229 * * *$ & $0.371 * * *$ & $-0.247 * * *$ \\
\hline
\end{tabular}




\section{Table 4}

Results of the Tobit regressions for executive, institutional, independent and female directors on boards Estimated coefficients (p-value). CSR_IN is measured as the ratio between the aggregation of the items that the firm provides of a total of 5 items and the total items considered; EXEC_DIR is the proportion of executive directors on board; INST_DIR is the proportion of institutional directors on board; INDP_DIR is the proportion of independent directors on boards; WOM_DIR is the proportion of female directors on boards; CEO_DUAL is calculated as Dummy variable equals to 1 if the same person serves simultaneously as CEO and President of the board and zero, otherwise; OWNCON is the ownership concentration in the firm; BDSIZE is the number of directors on boards; LEV is the debt over total assets; ROA is the operate income before interests and taxes over total assets; FIRMSIZE is the log of total sales. Significant at $* * *$ for 99 percent confidence level, $* *$ for 95 percent and $*$ for 90 percent.

\begin{tabular}{|c|c|c|c|c|c|}
\hline & $\begin{array}{l}\text { Expected } \\
\text { sign }\end{array}$ & $\begin{array}{c}\text { Model } 1 \\
\text { Estimated } \\
\text { coefficient } \\
\text { (p-value) }\end{array}$ & $\begin{array}{c}\text { Model } 2 \\
\text { Estimated } \\
\text { coefficient } \\
\text { (p-value) }\end{array}$ & $\begin{array}{l}\text { Model } 3 \\
\text { Estimated } \\
\text { coefficient } \\
\text { (p-value) }\end{array}$ & $\begin{array}{c}\text { Model } 4 \\
\text { Estimated } \\
\text { coefficient } \\
\text { (p-value) }\end{array}$ \\
\hline EXEC_DIR & - & $\begin{array}{l}-0.053 \\
(0.590)\end{array}$ & & & \\
\hline INST_DIR & + & & $\begin{array}{c}0.018 \\
(0.805)\end{array}$ & & \\
\hline INDP_DIR & + & & & $\begin{array}{l}0.074 * \\
(0.089)\end{array}$ & \\
\hline WOM_DIR & + & & & & $\begin{array}{l}0.026^{*} \\
(0.093)\end{array}$ \\
\hline CEO_DUAL & - & $\begin{array}{c}-0.093 * \\
(0.074)\end{array}$ & $\begin{array}{c}-0.093^{*} \\
(0.080)\end{array}$ & $\begin{array}{c}-0.100^{*} \\
(0.057)\end{array}$ & $\begin{array}{c}-0.094^{*} \\
(0.072)\end{array}$ \\
\hline OWNCON & + & $\begin{array}{c}0.011 \\
(0.861)\end{array}$ & $\begin{array}{c}0.003 \\
(0.964)\end{array}$ & $\begin{array}{l}0.010 \\
(0.874)\end{array}$ & $\begin{array}{c}0.002 \\
(0.971)\end{array}$ \\
\hline BDSIZE & + & $\begin{array}{c}0.005 \\
(0.174)\end{array}$ & $\begin{array}{c}0.005 \\
(0.197)\end{array}$ & $\begin{array}{c}0.004 \\
(0.189)\end{array}$ & $\begin{array}{c}0.004 \\
(0.197)\end{array}$ \\
\hline LEV & + & $\begin{array}{l}-0.120 \\
(0.153)\end{array}$ & $\begin{array}{l}-0.120 \\
(0.157)\end{array}$ & $\begin{array}{l}-0.120 \\
(0.158)\end{array}$ & $\begin{array}{l}-0.124 \\
(0.143)\end{array}$ \\
\hline ROA & + & $\begin{array}{c}0.004 \\
(0.877)\end{array}$ & $\begin{array}{c}0.003 \\
(0.911)\end{array}$ & $\begin{array}{c}0.000 \\
(0.999)\end{array}$ & $\begin{array}{c}-0.001 \\
(0.971)\end{array}$ \\
\hline FIRMSIZE & + & $\begin{array}{c}0.034 * * * \\
(0.000)\end{array}$ & $\begin{array}{c}0.034 * * * \\
(0.000)\end{array}$ & $\begin{array}{c}0.033 * * * \\
(0.000)\end{array}$ & $\begin{array}{c}0.034 * * * \\
(0.000)\end{array}$ \\
\hline Observations & & 159 & 159 & 159 & 159 \\
\hline Test & & $\begin{array}{c}460.79 * * * \\
(0.000)\end{array}$ & $\begin{array}{c}471.86^{* * * *} \\
(0.000)\end{array}$ & $\begin{array}{c}457.03 * * * * \\
(0.000)\end{array}$ & $\begin{array}{c}470.69 * * * \\
(0.000)\end{array}$ \\
\hline
\end{tabular}

